\title{
Analysis of Runoff Coefficient Value on Retention Ponds in Flores Island
}

\author{
Denik Sri Krisnayanti ${ }^{1}$, Wilhelmus Bunganaen ${ }^{1}$ Elsy E. Hangge ${ }^{1}$, Farah \\ Munaisyah $^{2}$, Nurul A. Nursyam ${ }^{2}$, Dian Noorvy Khaerudin ${ }^{3}$ \\ ${ }^{1}$ Department of Civil Engineering, Nusa Cendana University, Kupang, 85001, \\ Indonesia \\ ${ }^{2}$ Graduate School of Civil Engineering Department, Nusa Cendana University, \\ Kupang, 85001, Indonesia \\ ${ }^{3}$ Department of Civil Engineering, Tribuwana Tunggadewi University, Malang, \\ 85001, Indonesia \\ denik.krisnayanti@gmail.com
}

Received 03-11-2018; revised 27-12-2018; accepted 28-02-2019

\begin{abstract}
Flores Island is one of four big islands in NTT province with an area $\pm 13,540 \mathrm{~km}^{2}$ divided into 8 districts. The area is included in areas with unequal distribution of rainfall. Therefore, the amount of water availability during the dry season is relatively low then require to attempts of rainwater harvesting. One of the alternatives is by building a retention pond. The important parameter in the calculation of water availability is the value of runoff coefficient. The purpose of this research is to invent the runoff coefficient value of 30 retention ponds in 8 districts of Flores Island. In this study use rainfall data, climatology and technical of retention basin for the analysis of run off coefficient. The analysis method uses the Penman modification for evapotranspiration calculation and method F.J. Mock for discharge calculation. The result in graphical model uses monthly rainfall data and land slope data. Based on the analytical calculation method, the value of run off coefficient for each district in Flores was ranging $0.00-0.72$. The minimum value of runoff coefficient happened in November was ranging from $0.00-0.39$, and the maximum value of runoff coefficient happened in January was ranging from $0.48-0.72$.
\end{abstract}

Keywords: retention ponds; evapotranspiration; runoff coefficient

\section{Introduction}

Flores Island is a region that has different climatological conditions which the western Flores is wetter than eastern parts. One of the effective strategies in resolving the lack of water supply in semi-arid area, that is with harvesting rainwater as build retention pond or retention basin. The important parameter to calculate of water availability at retention ponds is the coefficient of runoff. The value of runoff coefficient is a number that shows the ratio of surface runoff occurs against the volume of rainfall in a region. Runoff coefficient value needed to calculate water discharge inflow to the retention ponds. 
One way to resolve the problem of lack the water availability is building the retention ponds construction. Retention ponds or usually called "embung" serves as a place to store the excess water during the rainy season. The excess of rainwater is stored by "embung" can be utilized during the dry season to fulfil the requirement of water for the population, cattle, and garden. Besides the rainwater falls on the surface to the retention ponds, some of the water also comes from the surface runoff [9].

Run off from catchment must be adequate to meet requirements. In practise, the catchment should be neither too small nor too large [5]. First, it will not meet the requirements, and second, the rapid sedimentation caused by the silt carried by the stream. The loss in storage capacity is attributed to the accumulation of sediment in the retention ponds [4].

Surface runoff occurs when the rainfall is greater than the ability of the soil to absorb water. So that the excess water flows down to the river, lake, or sea. One indicator that determines the amount of surface runoff is the value of runoff coefficient. The runoff coefficient is mentioned "high" when it close to 1.00 , which indicates that more rainwater becomes the surface runoff. But if the rainwater percolate as infiltration to underground then the runoff coefficient is close to 0 .



Figure 1. The retention pond in Larantuka - Flores Island

Water availability of a retention ponds are obtained from the discharge entering the catchment area due to the high intensity rainfall. Those discharge influences the value of runoff coefficient that one of important factor in water conservation for planning of retention pond development. The value of the runoff coefficient in an area also variety depends on the meteorological conditions and the land cover conditions of the watershed [8].

In this study use rainfall data, climatology and technical of retention basin for the analysis of run off coefficient. The analysis method uses the Penman modification for evapotranspiration calculation and method F.J. Mock for discharge calculation. Evapotranspiration (Ep) is the combination of two separate processes, where liquid water is converted to water vapour (vaporization) from the soil, wet vegetation, open water or other surfaces, as well as from plants by transpiration through stomata [1]. Potential evapotranspiration is evaporation that affected by climatic conditions. The main weather variables affecting Ep are temperature, solar radiation, wind speed and vapour pressure. The calculation of evapotranspiration method uses the Penman Modification method and can be formulated as follows:

$$
\mathrm{Ep}=\mathrm{c}[\mathrm{w} \times \mathrm{Rn}+(1-\mathrm{W}) \times \mathrm{f}(\mathrm{u}) \times(\mathrm{ea}-\mathrm{ed})]
$$

whereas:

Ep $=$ potential evapotranspiration $(\mathrm{mm} /$ month $)$ 
$\mathrm{c} \quad=$ adjustment factor to compensate for the day and night weather effects

$\mathrm{w}=$ temperature and elevation related weighting factor for the effect of radiation on Ep

$\mathrm{Rn}=$ net radiation $\left(\mathrm{Rns}-\mathrm{Rn}_{\mathrm{l}}\right)$ in $\mathrm{mm} /$ day

$(1-\mathrm{w})=$ a temperature and elevation related weighting factor and the effect of wind humidity on

Ep

$\mathrm{f}(\mathrm{u})=\mathrm{a}$ wind $(\mathrm{km} /$ day $)$ related function $=0.27(1+(\mathrm{U} / 100))$

ea $=$ saturation vapor pressure at the mean air temperature in degrees centigrade (mbar)

ed $=$ mean actual vapor pressure of air in $\mathrm{mbar}=\mathrm{ea}(\mathrm{RH} / 100)$

$\mathrm{RH}=$ relative humidity

The calculate of dependable flow by FJ Mock method is a calculation method based on rainfall data, evapotranspiration, and local hydrological characteristics. The calculation criteria of simulation FJ Mock method include analysis:

(a) Rainfall data,

(b) Limited evapotranspiration,

$$
\mathrm{Et}=\mathrm{Ep}-\mathrm{E}
$$

(c) Water balance,

$\Delta \mathrm{S}=\mathrm{P}-\mathrm{Et}$

$\mathrm{WS}=\Delta \mathrm{S}-\mathrm{SS}$ and $\mathrm{WS}=0$ if $\Delta \mathrm{S}<\mathrm{SS}$

$\mathrm{WS}=0$ if $\Delta \mathrm{S}<\mathrm{SS}$

(d) Runoff and groundwater storage,

$$
\begin{aligned}
& \Delta \mathrm{V}_{\mathrm{n}}=\mathrm{V}_{\mathrm{n}}-\mathrm{V}_{(\mathrm{n}-1)} \\
& \mathrm{Vn}=\mathrm{k} \mathrm{V}(\mathrm{n}-1)+0.5(1+\mathrm{k}) \mathrm{I} \\
& \mathrm{I}=\text { WS x In }
\end{aligned}
$$

whereas:

$$
\begin{aligned}
& \text { Et = limited evapotranspiration, } \\
& \text { Ep }=\text { potential evapotranspiration, } \\
& \mathrm{E} \quad=\text { the difference between Et and Ep }(\mathrm{mm}) \\
& \mathrm{WS}=\text { excess water }(\mathrm{mm} / \mathrm{month}) \\
& \Delta \mathrm{S}=\text { effective rainwater }(\mathrm{mm} / \mathrm{month}) \\
& \text { if } \Delta \mathrm{S}<0 \text {, then the surplus water }=0 \\
& \mathrm{SS}=\text { groundwater content }(\mathrm{mm}) \\
& \Delta \mathrm{Vn}=\text { deviation of groundwater storage volume ( } \mathrm{mm} / \mathrm{month}) \\
& \mathrm{Vn} \quad=\text { volume of ground water deposits month } \mathrm{n}(\mathrm{mm} / \mathrm{month}) \\
& \mathrm{K}=\mathrm{qt} / \mathrm{qo}=\text { soil recession factor (assumed } 0-1) \\
& \text { Vn-1 = volume of ground water savings month }(\mathrm{n}-1)(\mathrm{mm} / \mathrm{month}) \\
& \text { I }=\text { volume of ground water savings month } n(\mathrm{~mm} / \mathrm{month}) \\
& \text { In } \quad=\text { infiltration coefficient (assumed } 0-1)
\end{aligned}
$$

(e) Dependable flow, consist of [11]:

Base flow $(\mathrm{BF})=$ infiltration $(\mathrm{I})-$ deviation the volume of ground water $\left(\Delta \mathrm{V}_{\mathrm{n}}\right)$

Direct runoff $(\mathrm{DR})=$ excess water $(\mathrm{WS})$ - infiltration (I)

Flow $=$ Base flow $(B F)+$ Direct runoff $(D R)$

(f) Runoff Coefficient

The runoff coefficient is defined as the ratio between the peak of surface runoff to the intensity of rainfall. This factor is the most variable that determine the calculation results of flood discharge. The main factors affecting the runoff coefficient are the rate of soil infiltration or percentage of impermeable land, land slope, land covering and intensity of rainfall [10].

In the calculation of surface runoff coefficient analysis used with analytical method as follows [2]:

- Count the average rainfall in catchment area at the given time (t), e.g. $\mathrm{P}=\mathrm{mm} / \mathrm{month}$, 
- Change the unit of rainfall into $\mathrm{m} / \mathrm{month}$ by multiplying $1 / 1,000$, so that the rainfall becomes $\mathrm{P} / 1,000 \mathrm{~m} / \mathrm{month}$,

- Count the amount of water flow in the month (t) by way of:

- $\quad$ Runoff volume $=\mathrm{n} \times 86,400 \times \mathrm{Q}$ whereas:

$$
\begin{aligned}
& \mathrm{n}=\text { number of days in a month } \\
& \mathrm{Q}=\text { the average of monthly discharge }\left(\mathrm{m}^{3} / \mathrm{s}\right)
\end{aligned}
$$

- $\quad$ Rainfall volume $=\mathrm{P} / 1,000 \times \mathrm{A}$

- $\quad$ Runoff coefficient $=$ runoff volume/rainfall volume

Research and Development Centre for Water Resources, previously also had conducted an analysis of the value of runoff coefficient in retention ponds. That analysis produces the graphs that could be used to determine the value of runoff coefficients [7]. The aim of this study is to know the value of runoff coefficient on 30 retention ponds in Flores Island with using analytical method. The calculation results compared with graph of Research and Development Centre for Water Resources [7].

\section{Material and Methods}

The calculation of runoff coefficient value has done by taking sample of 30 retention ponds in Flores Island that built from 2010 - 2014. Flores island has many rainfall stations but only 12 active rainfall stations [3]. This research carried out on a few of retention ponds scattered in Flores Island as many as 30 (thirty) small ponds. The selected retention ponds data from eight districts in Flores Island are:
1) East Flores
2) Sikka
3) Ende
4) Nagekeo
5) Ngada
6) East Manggarai
7) Manggarai
8) West Manggarai

: Belohuko, Angi Marak, Gajak Leda, and Sabu Leti,

: Waer Koja, Mageweda, Napunggelang and Habiheret,

: Korangawe, Aenangge, Tanah Merah, and Tubu Bewa,

: Nunu Beza, Kelimeli and Robo Alo,

: Hoboremangai, Ndoraliti, Ngara I, Ramba I, Budhai, and Tanah Ewer,

: Waekao, Komba, Kempo, and Hedok,

: Kondang and Pedang Mari,

: Nara I, Joneng, and Waecere.

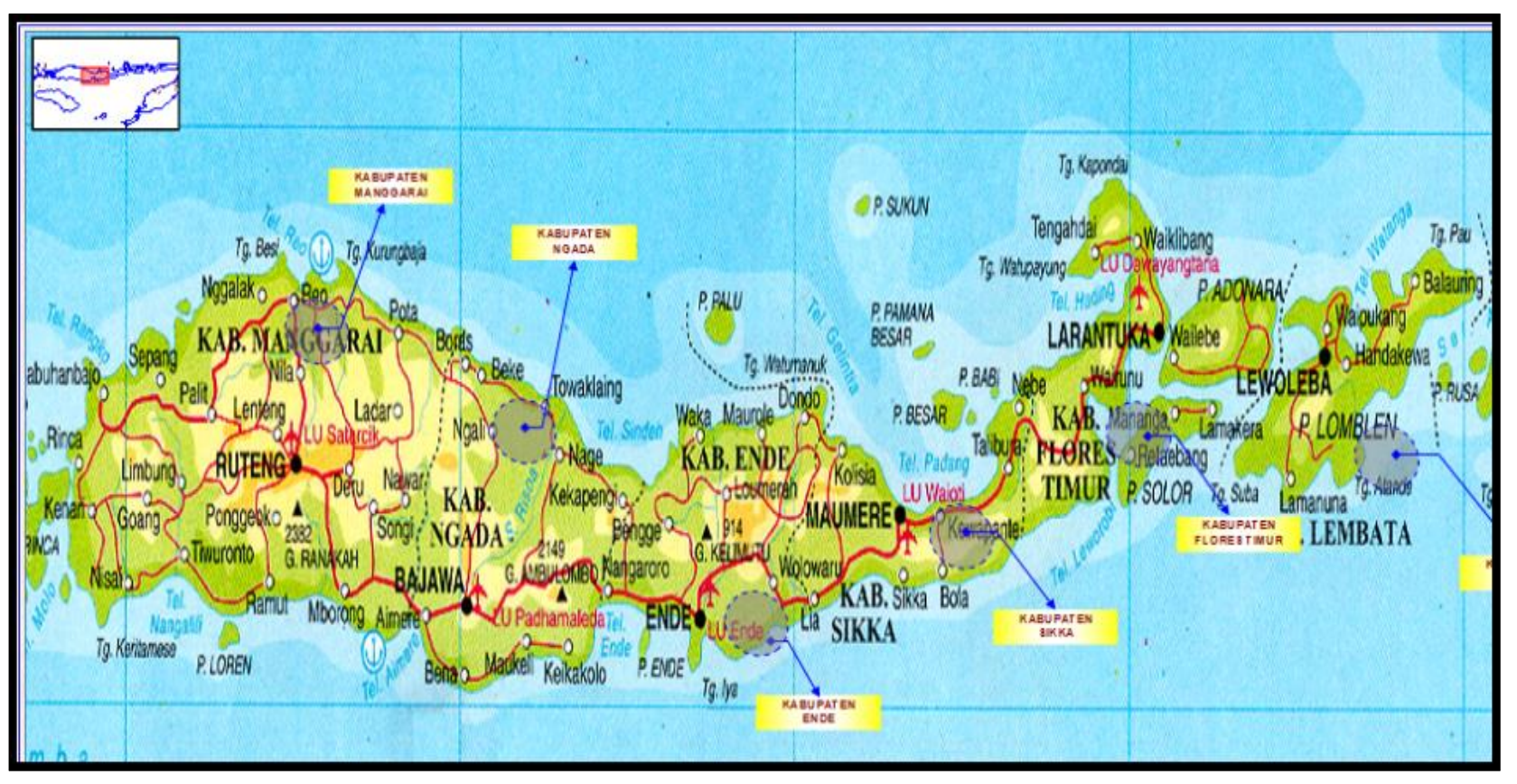

Figure 2. Layout of Flores Island in East Nusa Tenggara 
Methods carried out with: a) descriptive study, i.e. by doing literature study and collecting of secondary data such as topographic maps, precipitation data, climate data and land use of the watershed; b) qualitative research, i.e. from descriptive studies were transferred in the form of charts to be used as a reference in the calculation to criteria design of retention ponds. Flow chart of the method shown in Figure 3.

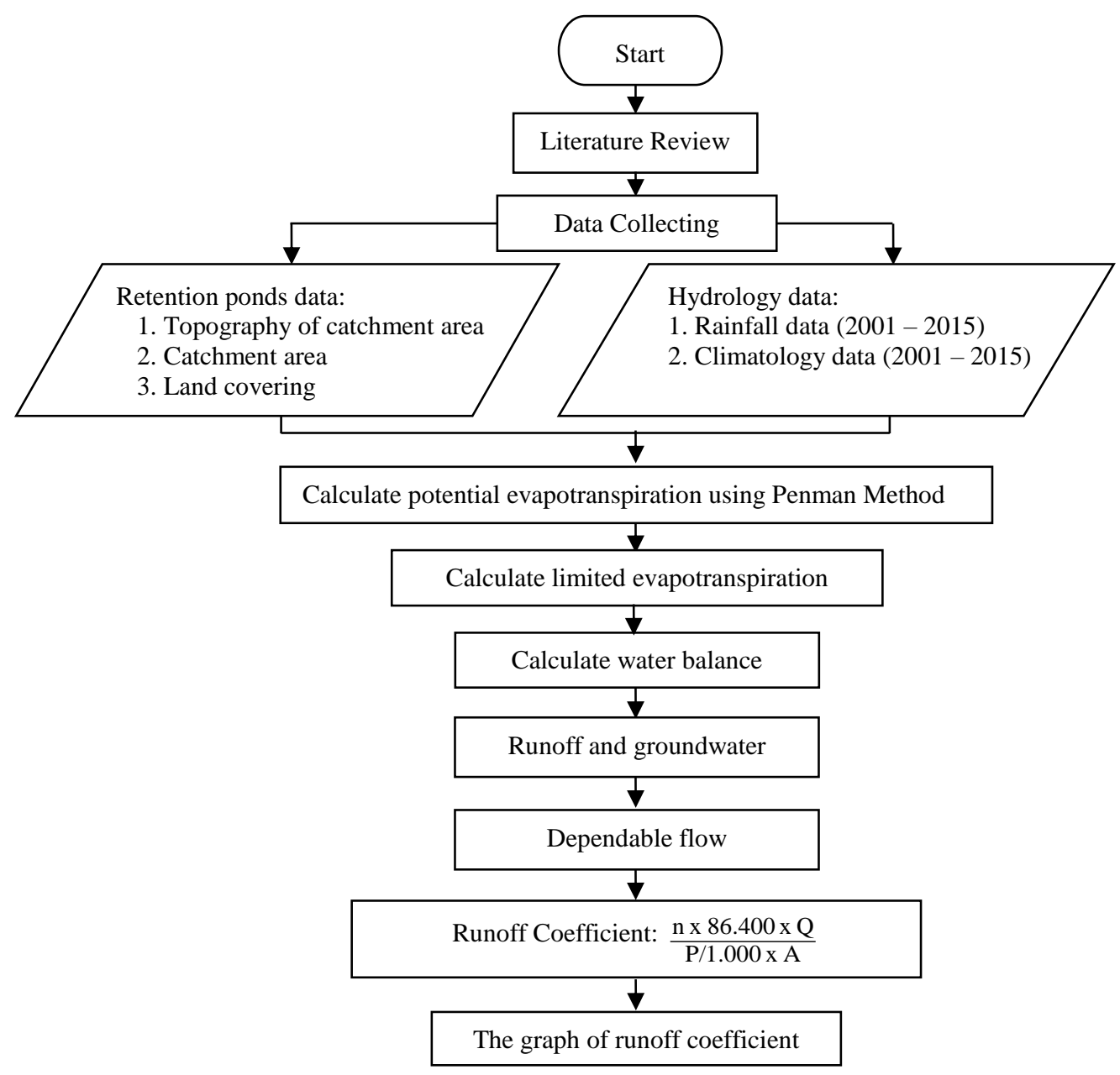

Figure 3. Flow chart of the research [6]

\section{Result and Discussion}

The value of surface runoff coefficient is a number that shows the ratio of the amount of surface flow that occurs as a result of the amount of rainfall that falls in a region against the volume of rainfall. The coefficient values are generally different in each region, depends on the permeability and the soil ability to keep water.

Data of monthly rainfall taken from rainfall stations which expected to represent phenomena of rainfall that occurred retention ponds location in Flores Island. The calculate of runoff coefficient with analytical and uses graph of Research and Development Centre for Water Resources or called 'Puslitbang' [7] in January shown in Table 1. 
Table 1. The value of runoff coefficient on 30 retention ponds in Flores Island in January

\begin{tabular}{|c|c|c|c|c|c|}
\hline \multirow{2}{*}{ District } & \multirow{2}{*}{$\begin{array}{c}\text { Retention } \\
\text { Ponds } \\
\end{array}$} & \multirow{2}{*}{$\begin{array}{c}\text { Slope of land } \\
(\mathbf{m} / \mathbf{k m}) \\
\end{array}$} & \multirow{2}{*}{$\begin{array}{c}\text { Monthly Rainfall } \\
(\mathbf{m m})\end{array}$} & \multicolumn{2}{|c|}{ Runoff coefficient } \\
\hline & & & & Analytical & Graph \\
\hline Sikka & Waer Koja & $<100$ & 181.50 & 0.26 & 0.04 \\
\hline Sikka & Mageweda & $<100$ & 144.56 & 0.37 & 0.01 \\
\hline Sikka & Napunggelang & $<100$ & 144.56 & 0.37 & 0.01 \\
\hline Sikka & Habiheret & $<100$ & 181.50 & 0.26 & 0.04 \\
\hline Ende & Korangawe & $<100$ & 289.53 & 0.65 & 0.22 \\
\hline Ende & Aenangge & $<100$ & 289.53 & 0.60 & 0.48 \\
\hline Ende & Tana Merah & $<100$ & 289.53 & 0.58 & 0.22 \\
\hline Ende & Tubu Bewa & $<100$ & 253.80 & 0.55 & 0.40 \\
\hline Nagakeo & Nunu Beza & $<100$ & 472.20 & 0.68 & 0.62 \\
\hline Nagakeo & Kelimeli & $<100$ & 472.20 & 0.67 & 0.62 \\
\hline Nagakeo & Robo Alo & $<100$ & 472.20 & 0.67 & 0.62 \\
\hline West Manggarai & Joneng & $<100$ & 220.20 & 0.34 & 0.10 \\
\hline East Manggarai & Waekao & $<100$ & 160.07 & 0.18 & 0.04 \\
\hline East Manggarai & Komba & $<100$ & 160.07 & 0.17 & 0.04 \\
\hline Ngada & Ndoraliti & $<100$ & 525.87 & 0.76 & 0.63 \\
\hline Ngada & Budhai & $<100$ & 525.87 & 0.76 & 0.63 \\
\hline Ngada & Tanah Ewer & $<100$ & 525.87 & 0.76 & 0.63 \\
\hline East Flores & Belohuko & $100-200$ & 372.40 & 0.54 & 0.52 \\
\hline East Flores & Angi Marak & $100-200$ & 372.40 & 0.54 & 0.52 \\
\hline East Flores & Gajak Leda & $100-200$ & 372.40 & 0.53 & 0.61 \\
\hline East Flores & Sabu Leti & $100-200$ & 372.40 & 0.52 & 0.61 \\
\hline West Manggarai & Nara I & $100-200$ & 220.20 & 0.36 & 0.34 \\
\hline West Manggarai & Waecere & $100-200$ & 220.20 & 0.35 & 0.34 \\
\hline East Manggarai & Kempo & $100-200$ & 160.07 & 0.19 & 0.15 \\
\hline East Manggarai & Hedok & $100-200$ & 160.07 & 0.17 & 0.15 \\
\hline Manggarai & Kondamari & $100-200$ & 427.40 & 0.73 & 0.63 \\
\hline Ngada & Ramba I & $100-200$ & 525.87 & 0.75 & 0.63 \\
\hline Ngada & Hoboremangai & $100-200$ & 525.87 & 0.76 & 0.63 \\
\hline Ngada & Ngara I & $100-200$ & 525.87 & 0.76 & 0.63 \\
\hline Manggarai & Pedang & $>200$ & 427.40 & 0.72 & 0.81 \\
\hline
\end{tabular}

Based on the analysis data in Table 1, the value of runoff coefficient between analytical method and by using 'Puslitbang' graph on 30 retention ponds have differences of about $23.52 \%$. Only three districts have a considerable difference i.e. Sikka, Ende, and in part of East Manggarai.

For the overall calculation of surface runoff coefficient values for each district in Flores Island can be seen in Table 2 . 
Table 2. Recapitulation of the value of runoff coefficient on 30 retention ponds in Flores Island

\begin{tabular}{|c|c|c|c|c|c|c|c|c|c|c|c|c|}
\hline \multirow{2}{*}{$\begin{array}{c}\text { Name of retention } \\
\text { ponds }\end{array}$} & \multicolumn{12}{|c|}{ Month } \\
\hline & Jan & Feb & March & Apr & May & Jun & Jul & Aug & Sept & Oct & Nov & Dec \\
\hline Belohuko & 0.538 & 0.554 & 0.472 & 0.432 & 0.283 & 0.952 & 0.107 & 0.081 & 0.004 & 0.000 & 0.000 & 0.274 \\
\hline Angi Marak & 0.536 & 0.540 & 0.472 & 0.431 & 0.282 & 0.948 & 0.106 & 0.080 & 0.004 & 0.000 & 0.000 & 0.286 \\
\hline Gajak Leda & 0.533 & 0.549 & 0.467 & 0.426 & 0.276 & 0.935 & 0.105 & 0.079 & 0.003 & 0.000 & 0.000 & 0.269 \\
\hline Sabu Leti & 0.523 & 0.539 & 0.458 & 0.413 & 0.261 & 0.898 & 0.101 & 0.076 & 0.003 & 0.000 & 0.000 & 0.259 \\
\hline Waer Koja & 0.264 & 0.314 & 0.262 & 0.333 & 0.367 & 0.126 & 0.574 & 0.010 & 0.002 & 0.000 & 0.012 & 0.239 \\
\hline Mageweda & 0.372 & 0.373 & 0.418 & 0.451 & 0.413 & 0.340 & 0.089 & 0.000 & 0.004 & 0.001 & 0.000 & 0.201 \\
\hline Napunggelang & 0.373 & 0.375 & 0.420 & 0.453 & 0.415 & 0.342 & 0.089 & 0.000 & 0.004 & 0.001 & 0.000 & 0.201 \\
\hline Habiheret & 0.261 & 0.324 & 0.279 & 0.350 & 0.380 & 0.131 & 0.120 & 0.010 & 0.002 & 0.000 & 0.019 & 0.251 \\
\hline Korangawe & 0.652 & 0.643 & 0.598 & 0.511 & 0.417 & 0.282 & 0.086 & 0.055 & 0.304 & 0.104 & 0.031 & 0.477 \\
\hline Aenangge & 0.599 & 0.574 & 0.531 & 0.413 & 0.292 & 0.168 & 0.056 & 0.035 & 0.261 & 0.054 & 0.004 & 0.399 \\
\hline $\mathrm{Ta}$ & 0.577 & 51 & 0.511 & & & 33 & & 030 & 248 & 39 & 003 & 382 \\
\hline Tubu Bewa & 0.554 & 0.611 & 0.551 & 0.533 & 0.434 & 0.160 & 0.102 & 0.040 & 0.533 & 0.273 & 0.030 & 0.445 \\
\hline Nunu Beza & 0.680 & 0.645 & 0.542 & 0.548 & 0.374 & 0.482 & 0.386 & 0.228 & 0.208 & 0.153 & 0.383 & 0.633 \\
\hline Kelimeli & 0.675 & 0.637 & 0.530 & 0.537 & 0.361 & 0.475 & 0.368 & 0.222 & 0.200 & 0.146 & 0.375 & 0.629 \\
\hline Robo Alo & 0.674 & 0.637 & 0.530 & 0.536 & 0.360 & 0.475 & 0.367 & 0.221 & 0.199 & 0.145 & 0.375 & 0.628 \\
\hline Budhai & & & & & & & & 0.337 & & & 80 & \\
\hline Hoboremangai & 0.756 & 0.781 & 0.769 & 0.714 & 0.628 & 0.602 & 0.460 & 0.339 & 0.282 & 0.185 & 0.580 & 0.685 \\
\hline Ndoraliti & 0.760 & 0.785 & 0.774 & 0.720 & 0.636 & 0.606 & 0.461 & 0.347 & 0.285 & 0.191 & 0.585 & 0.688 \\
\hline Ngara I & 0.761 & 0.786 & 0.777 & 0.722 & 0.640 & 0.608 & 0.462 & 0.351 & 0.287 & 0.194 & 0.587 & 0.690 \\
\hline Ramba I & 0.754 & 0.777 & 0.759 & 0.699 & 0.598 & 0.588 & 0.426 & 0.301 & 0.278 & 0.162 & 0.569 & 0.682 \\
\hline Tanah Ew & & 0.784 & 0.774 & & 0.636 & 0.606 & 0.461 & 0.347 & 0.285 & 0.191 & 0.585 & 0.688 \\
\hline Hedok & 0.168 & 0.218 & 0.209 & 0.164 & 0.050 & 0.037 & 0.170 & 0.060 & 0.013 & 0.006 & 0.148 & 0.175 \\
\hline Kempo & 0.192 & 0.246 & 0.238 & 0.187 & & 0.041 & 0.170 & 0.061 & 0.013 & 0.020 & 0.161 & 0.197 \\
\hline Komba & 0.172 & 0.223 & 0.214 & 0.169 & 0.052 & 0.038 & 0.170 & 0.060 & 0.013 & 0.009 & 0.151 & 0.179 \\
\hline Waekao & 0.175 & 0.227 & 0.218 & 0.172 & 0.052 & 0.038 & 0.170 & 0.060 & 0.013 & 0.011 & 0.152 & 0.182 \\
\hline Kondama1 & 0.731 & 0.781 & 0.759 & 0.823 & 0.779 & 0.651 & 0.409 & 0.225 & 0.354 & 0.409 & 0.639 & 0.707 \\
\hline Pedang & 0.725 & 0.776 & 0.754 & 0.818 & 0.771 & 0.639 & 0.404 & 0.220 & 0.346 & 0.400 & 0.633 & 0.702 \\
\hline Embung Joneng & 0.343 & 0.212 & 0.228 & 0.233 & 0.152 & 0.077 & 0.037 & 0.089 & 0.011 & 0.002 & 0.000 & 0.197 \\
\hline Nara I & 0.355 & 0.230 & 0.241 & 0.241 & 0.166 & 0.082 & 0.039 & 0.102 & 0.013 & 0.002 & 0.000 & 0.211 \\
\hline Waecere & 0.346 & 0.216 & 0.231 & 0.235 & 0.155 & 0.079 & 0.037 & 0.092 & 0.012 & 0.002 & 0.000 & 0.200 \\
\hline Maximum & 0.761 & 0.786 & 0.777 & 0.823 & 0.779 & 0.952 & 0.574 & 0.351 & 0.533 & 0.409 & 0.639 & 0.707 \\
\hline Minimum & 0.168 & 0.212 & 0.209 & 0.164 & 0.050 & 0.037 & 0.037 & 0.000 & 0.002 & 0.000 & 0.000 & 0.175 \\
\hline Average & 0.519 & 0.523 & 0.492 & 0.469 & 0.372 & 0.405 & 0.235 & 0.139 & 0.149 & 0.096 & 0.220 & 0.415 \\
\hline
\end{tabular}

Table 2 shows that the value of runoff coefficient in December until April have a greater value than another month. This is because the rainfall is quite high and lead to greater runoff. Thus, the filling of water ponds fulfilled in that months. In August - November, almost of all the retention ponds weren't receiving runoff from upstream due to dry season in Flores island.

For the graph of runoff coefficient against high of monthly rainfall and slope of the land in January - April shown in Figure 3. 




(a) January

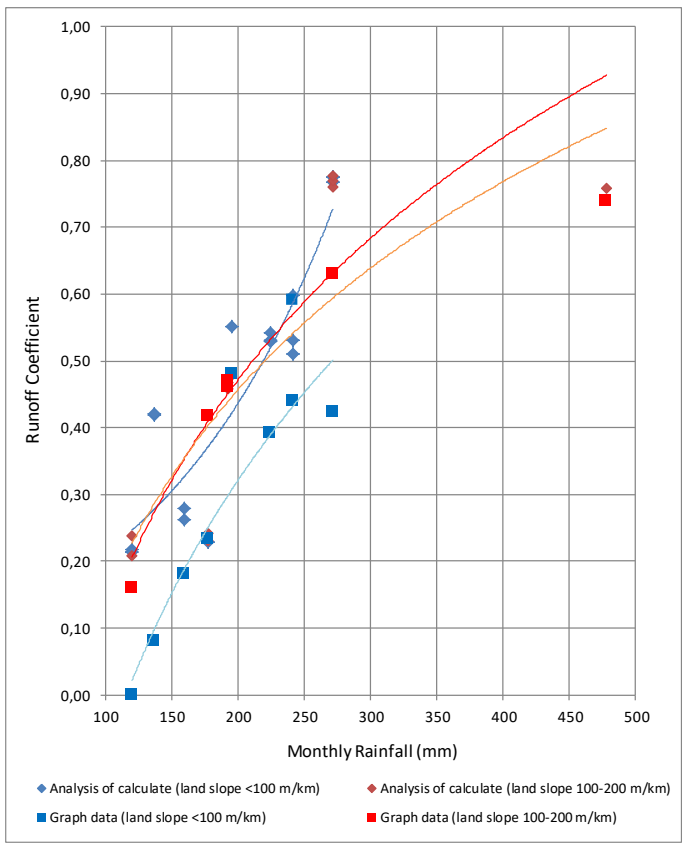

(c) March

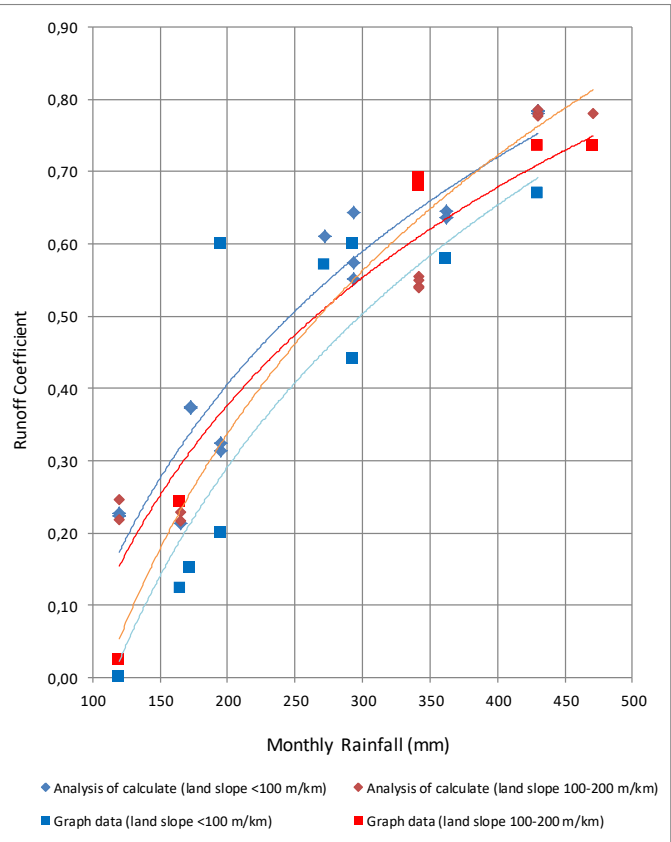

(b) February

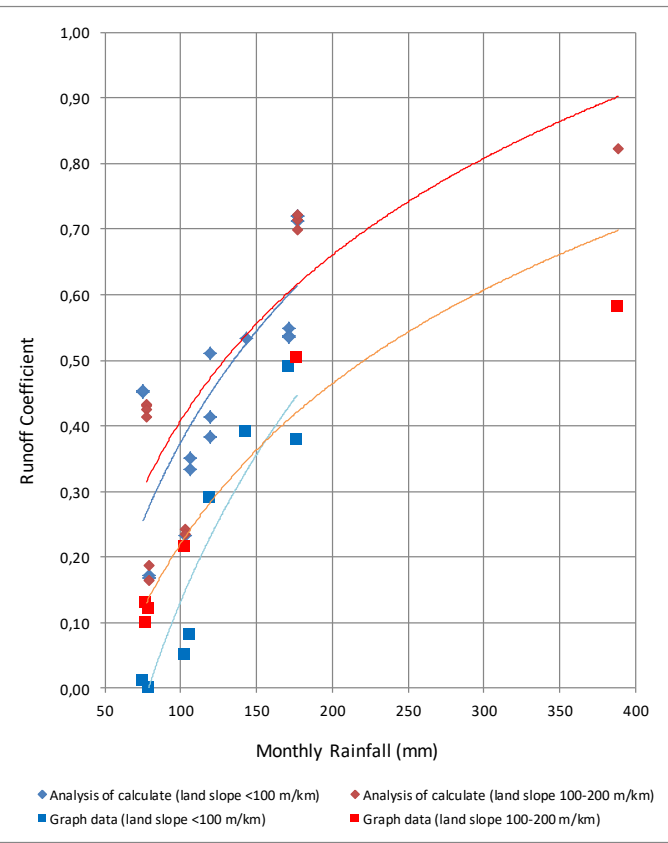

(d) April

Figure 4. Graph high of monthly rainfall and slope of the land against runoff coefficient in the western part of Flores Island

Based on Figure 4 can be seen that the value of runoff coefficient in January and February has a tendency higher than March - April. In addition, the value of runoff coefficient is evenly distributed at the height of monthly rainfall than in March - April.

The difference value of calculation in January - April has ranging $10-20 \%$ higher than graph data from Research and Development Centre for Water Resources [7]. This is due to the transfer of land functions from forests into gardens or housing that make a lack of the catchment areas and decreasing 
green land cover. It is resulting in greater surface runoff when it rains. Land-use and land-cover changes may have direct impacts on the hydrological cycle: they can cause floods, droughts, and changes in river and groundwater regimes [12].

\section{Conclusions}

The value of runoff coefficient by analysis for 30 retention ponds in Flores Island is as follows: a) West Flores (West Manggarai, Manggarai, East Manggarai, Ngada and Nagekeo) have the average of runoff coefficient value $0.12-0.61$. The highest average of runoff coefficient value in Manggarai, Ngada, and Nagekeo. While other region has a low runoff coefficient value; b) East Flores (Ende, Sikka, and East Flores) have the average of runoff coefficient value $0.21-0.31$. The value of runoff coefficient in this region lower because the eastern regions in Flores of the climate are drier so that the soil characteristic is more porous.

The runoff coefficient value based on analysis of calculate tends to be higher when compared with graph data from Research and Development Centre for Water Resources. This is due to the transfer of land functions or change land covering in catchment area. It is resulting in greater surface runoff when it rains.

\section{Acknowledgements}

The authors thank to The Ministry of Technology Research and Higher Education - Indonesia in the financial support of The Program of Applied Product Research in 2015 - 2017.

\section{References}

[1] Allen, R.G. Pereira,L.S. Raes, Dirk. Smith, Martin. 1998. Crop evapotranspiration - Guidelines for computing crop water requirements - FAO Irrigation and drainage paper 56. Rome.

[2] Asdak, C. 2010. Hydrology and Watershed Management. Gadjah Mada University Press, Yogyakarta.

[3] Department of Public Works, NTT Province. 2011. Final Report "Planning Study of 15 Retention ponds in Timor Island, Rote and Alor", PT. Indra Karya, Kupang.

[4] Heitz, L.F. Khosrowpanah, S. Nelson, J. 2000. Sizing of Surface Water Runoff Detention Ponds For Water Quality Improvement, Journal of The American Water Resources Association. Volume 36, Issue 3, Pages 541-548.

[5] Lewis, B. 2014. Small Dams. Planning, Construction, and Maintenance. CRC Press. London, UK.

[6] Krisnayanti,D.S. Bunganaen,W. 2015. The Graph Analysis of Run Off Coefficient Values on Small 'Embung' Design Criteria in South Central Timor - NTT. Proceeding of National Conference $3^{\text {rd }}$, Faculty of Civil Engineering and Planning, UII, Yogyakarta.

[7] Kasiro, dkk. 1994. Guideline for 'Small Embung' Design Criteria for Semiarid Area in Indonesia. Research and Development Centre for Water Resources, Department of Public Works. Jakarta.

[8] Sosrodarsono. 2003. Hydrology for Irrigation. Department of Public Works and Electric Power. PT. Pradnya Paramita. Jakarta.

[9] Soemarto, C. D. 1986. Hydrology Technique. PT. Erlangga. Jakarta.

[10] Suripin. 2004. Development of Sustainable Drainage System. Andi Offset, Yogyakarta.

[11] Sutapa, I Wayan. 2015. Study Water Availability of Malino River to Meet the Need of Water Requirement in District Ongka Malino, Central Sulawesi of Indonesia. International Journal of Engineering and Technology, Vol 7 No 3 Jun-Jul 2015. Tamil Nadu, India.

[12] Weng, Q. 2001. Modeling Urban Growth Effects on Surface Runoff with the Integration of Remote Sensing and GIS. Environmental Management Vol. 28, No. 6, pp. 737-748. SpringerVerlag New York Inc. 